\title{
Undervisningsbaserede forskningskollektiver: Fra studenterundervisning til akademiske partnerskaber
}

Rikke Toft Nørgård, lektor, Center for Undervisningsudvikling og Digitale Medier, Aarhus Universitet

Kim Haagen Mathiesen, kandidat i IT-didaktisk design 2017, Aarhus Universitet

\section{Videnskabelig artikel, fagfællebedømt}

Med modus 3 universitetet (Barnett, 2011; Bengtsen \& Nørgård, 2016) og Participatory Academic Communities (Aaen \& Nørgård, 2015) som rammeværk beskriver artiklen, hvordan traditionelle forskningsinformerede og -baserede undervisningsforløb kan gentænkes og rekonfigureres til forskningsproducerende undervisning, der faciliterer studerendes forskningsprocesser gennem oprettelsen af undervisningsbaserede forskerkolletiver og akademiske partnerskaber.

Artiklen tager udgangspunkt i kurset Design: teori, metode \& praksis på kandidatuddannelsen i IT-Didaktisk Design på Aarhus Universitet, der fungerer som didaktisk designeksperiment i form af et research through design (Collins, Joseph \& Bielaczyc, 2004; Dalsgaard, 2010). Artiklen tager udgangspunkt i én af projektgruppernes forløb, der tager sin begyndelse i faget og strækker sig 1 år efter fagets afslutning. Den ene af artiklens forfattere er studerende i projektgruppen, mens den anden af forfatterne er underviser på faget.

Artiklens formål er at pege på de potentialer, undervisningsbaserede forskningskollektiver har for at understøtte studerendes udformning af egen forskning, samt hvorledes sådanne kollektiver og processer kan skabe såkaldte modus 3-forbindelser mellem studerende, underviser, universitet og omverden. Sammenlagt peger forløbet på vigtigheden af, at de studerende oplever sig som ligeværdige partnere i kollektivet, hvor underviseren fungerer som med-forsker og med-tænker, og hvor deres bidrag har reel samfundsværdi. Ligeledes er det afgørende, at underviseren fungerer som mentor i forskningskollektivet, mens de studerende er ejere af egne forskningsprocesser og -projekter.

\section{Indledning}

Artiklen giver et bud på, hvordan undervisningsforløb på universitetet kan facilitere reelle forskningsprocesser gennem oprettelse af, hvad vi i artiklen kalder undervisningsbaserede forskningskollektiver. Med faget Design: teori, metode og praksis på kandidatuddannelsen IT-Didaktisk Design på Aarhus Universitet som case vises, hvordan almindelig holdundervisning kan gentænkes til at være egentlig forskningsproducerende med studerende og underviser som ligeværdige medforskere. Til forskel fra forskningsinformeret undervisning, der baserer sig på forskning, som underviseren har viden om, eller forskningsbaseret undervisning, der baserer sig på underviserens egen forskning eller forskningsfelt, så er forskningsproducerende undervisning en undervisningsform, der inviterer studerende til at indtage rollen som akademiske partnere på universitetet og være producenter af egen forskning. Undervisningsbaserede forskningskollektiver er som 
didaktisk design baseret på og en videreudvikling af Participatory Academic Communities (Aaen \& Nørgård, 2015).

Hovedformålet med at oprette undervisningsbaserede forskningskollektiver hvor studerende og undervisere fungerer som partnere, er at underst $\varnothing$ tte studerendes videnskabelige processer og produkter gennem udformning og udførsel af reelle forskningsprojekter. Målet er således at skabe processer og produkter af en sådan kvalitet, at de kan tælle som forskning gennem eksempelvis at kunne publiceres i pointgivende forskningspublikationer, blive optaget på peerreviewed forskningskonferencer, afvikles som offentlig formidling og udstilling eller som symposier for fagfæller - alt sammen noget, der har været udkommet af dette og tidligere gennemløb af kurset (se også Aaen \& Nørgård, 2015).

I undervisningsbaserede forskningskollektiver inviteres de studerende både til at være forskere, der deltager i egne designede, udførte og publicerede forskningsprocesser og -produkter (Fielding, 2001; Brew, 2003) og til at blive partnere i udviklingen og afviklingen af undervisningsfor$\mid \varnothing b$, -aktiviteter og curricula (Leat \& Reid, 2012). Alt dette finder sted i samspil med eksisterende formelle undervisningskrav, fastsatte læringsmål og affattelse af traditionelle eksamensopgaver.

Tilgangen i undervisningsbaserede forskningskollektiver er funderet på rammeværket fra Participatory Academic Communities (Aaen \& Nørgård, 2015). I disse deltagende akademiske fællesskaber arbejder de studerende projektorienteret, forskningsproducerende og visionsdrevet med at undersøge et selvvalgt emnefelt i krydsfeltet mellem personlig, uddannelsesmæssig og samfundsmæssig værdiskabelse på akademiske måder: "The concept of participatory academic communities entails an effort to connect society, people and institutions and to invest in each other" (Aaen \& Nørgård, 2015 s. 73). Hvad vi andetsteds også har kaldt for dannelse til 'akademisk medborgerskab' (Nørgård \& Bengtsen, 2016).

I undervisningsbaserede forskningskollektiver udvikler de studerende akademisk medborgerskab gennem at arbejde forskningsproducerende i reelle kontekster eller projektrammer, der rækker ud over undervisningsrummet. Gennem at indgå i disse kontekster eller projekter uden for institutionen opretter de studerende hybride partnerskaber mellem underviser/universitet og projektpartner/samfund, hvorigennem de indgår i dialog med omverdenen på akademiske måder og med underviser og projektpartner som med-forsker og mentor. Gennem dialoger og samarbejde i kollektivet udarbejder projektgrupperne forskningsspørgsmål, forskningsdesign, de indsamler, analyserer og præsenterer empiri og teori med det formål at nå frem til forslag, resultater, indsigter eller viden, der kan bringe såvel forskningen inden for området videre samt have relevans og værdi i samfundet, nærmere bestemt den kontekst eller det projekt, inden for hvilket det forskningsproducerende arbejde pågår.

Projektgruppernes arbejde i det undervisningsbaserede forskningskollektiv har indtil videre udmøntet sig i gennemførelse af et 20 ECTS-kursus, udstilling og formidling af gruppernes arbejde for offentligheden på DOKK1, peer-reviewed forskningsartikler (Mathiesen, Nedergaard \& Nørgård, 2016; Rygaard \& Nørgård, under udgivelse), samt præsentation og paper på forskningskonference (Mathiesen \& Nørgård, 2017).

Med udgangspunkt i én af disse projektgruppers arbejde - et forskningsprojekt omkring dialogisk læringsdesign af MOOCs (Massive Open Online Courses) - peger artiklen på centrale potentialer og muligheder ved at lade studerende og undervisere indgå i sådanne undervisningsbaserede forskningskollektiver. Men også væsentlige opmærksomhedspunkter og risici forbundet med at 
invitere studerende til at indtage rollen som ligeværdige forskere, sideløbende med at de fors $\varnothing$ ger at følge kurser og bestå eksaminer, fremdrages.

Afslutningsvis diskuteres nødvendigheden af i højere grad at anskue undervisning på universitetet som dialogisk, kollektiv, ligeværdig og demokratisk praksis mellem studerende og undervisere. Her kastes også et kritisk blik på de måder, hvorpå 'students as co-researchers \& coproducers' eller 'students as partners' ofte konceptualiseres og operationaliseres i undervisningssituationer eller forskningspraksis på universitetet.

\section{Metode}

Kurset Design: teori, metode og praksis kan anskues som et pågående flerårigt didaktisk designeksperiment i form af et research through design (Collins, Joseph \& Bielaczyc, 2004; Dalsgaard, 2010). Collins et al. påpeger, at designeksperimenter indenfor uddannelsesforskning som oftest tager udgangspunkt i tidligere forskning og teori indenfor et givent felt og ud fra dette udvikler og implementerer et design (Collins, Joseph \& Bielaczyc 2004, s. 18). I denne artikels tilfælde gælder det således udviklingen af undervisningsbaserede forskningskollektiver som didaktisk format, der igen er en videreudvikling af deltagende akademiske fællesskaber, som blev udviklet og beskrevet i Aaen \& Nørgård, 2015, der baserede sig på samme kursus i 2015. Inden for research through design er der tale om, at samme (lærings)design designes, evalueres og redesignes, således at der over tid fremkommer en formativ form for såvel forskningsbaseret viden som design:

Design experiments were developed as a way to carry out formative research to test and refine educational designs based on theoretical principles derived from prior research. This approach of progressive refinement in design involves putting a first version of a design into the world to see how it works. Then, the design is constantly revised based on experience, until all the bugs are worked out. (Collins, Joseph \& Bielaczyc, 2004, s. 18)

Kurset Design: teori, metode og praksis er iterativt gennem årene didaktisk designet gennem research through design ud fra overvejelser om modus 3 universitetet, forskningsproducerende undervisning og undervisningsbaserede forskningskollektiver med det formål at udvikle kritisk engagerede studerende-som-forskere. Collins et al. benævner de forskellige iterationer af designet som designeksperimentets faser, og denne artikel beskæftiger sig således med eksperimentets tredje fase, mens Aaen og Nørgård, 2015, beskæftigede sig med eksperimentets anden fase, og Nørgård, 2014, var et fors $\varnothing g$ på en første konceptualisering af formatet.

Foråret 2018 påbegyndes eksperimentets fjerde fase, hvor begreberne akademisk medborgerskab og academic activism tilkobles undervisningsbaserede forskningskollektiver i forsøget på ikke blot at forske, men aktivt deltage i og forandre den omverden og virkelighed, som universitetet er en del af.

Designeksperimentet beskrives som en intervenerende undersøgelsesmetode og er målrettet ikke kun at forbedre praksis, og undervisningsdesignet, men også at skabe teoretiske principper ud fra denne designpraksis: "Design research is not aimed simply at refining practice. It should also address theoretical questions and issues if it is to be effective" (Collins, Joseph \& Bielaczyc 2004 , s. 19). Denne artikel søger således at bidrage med principper for undervisningsbaserede forskningskollektiver, der udspringer fra faget Design: teori, metode og praksis' undervisningsdesign, som designeksperiment og research through design. 
Såvel Collins et al. (2004) som Dalsgaard (2010) beskriver designeksperimenter og research through design, som værende unders $\varnothing$ gelsesmetoder, der gør brug af mangfoldige former for empirisk materiale såsom videoer, interviews, feltnoter, studenterprodukter, evalueringer mv. som kilder til viden, designforskeren kan bygge sin undersøgelse og sit design på. I dette tilfælde har vi valgt at afgrænse vores materiale til en såkaldt eksemplarisk case (Flyvbjerg, 2010) i form af en konkret projektgruppes arbejde. I gruppen indgik som tidligere nævnt den ene af artiklens forfattere som studerende, mens den anden forfatter var underviser på kurset.

Undervisningsbaserede forskningskollektiver som format baserer sig således (ud over det teoretiske rammeværk, der præsenteres nedenfor) på: 1) den studerendes interaktioner, oplevelser og erfaringer som deltager i et sådant undervisningsbaseret kollektiv, 2) underviserens interaktioner, oplevelser og erfaringer som didaktisk designer, underviser og medforsker i selvsamme kollektiv, og 3) de studerendes eksamensprodukter og -opgaver samt deres evalueringer af kurset og diskussioner af dette i den fælles Facebook-gruppe. Sammenlagt spiller de 3 akser sammen og skaber 3 forskellige 'investigator' perspektiver (Stake, 1995).

Vores empiriske grundlag inkluderer således Facebook-gruppens billeder, opslag og diskussioner, studerendes og undervisers refleksive noter, formelle evalueringer fra samt et spørgeskema til alle studerende og endelig en kompilation af forskningskollektivets produkter i form af akademiske blogindlæg, eksamensopgaver, posters, videoer, prototyper mv., der dokumenterer forløbet. Den samlede årgangs akademiske blogindlæg, videoer, posters kan forefindes på årgangens fælles åbne akademiske blog her: https://pages-tdm.au.dk/platform/. Studenterprodukter, der er særlig relevante for artiklens case, er angivet i casebeskrivelsen og er ligeledes alle åbent tilgængelige. Specifikt kan gruppens blog tilgås her: https://pages-tdm.au.dk/itddfabfive/.

\section{Undervisningsdesignets grundlag: Akademiske partnerskaber på morgendagens universitet}

Før undervisningsbaserede forskningskollektiver præsenteres som didaktisk format, vil den forandrede universitetskontekst, på baggrund af hvilken undervisningsdesignet er intentionelt designet, først blive beskrevet. Det sker med det formål at etablere et rammeværk, ud fra hvilket etableringen af undervisningsbaserede forskningskollektiver kan anskues som et svar på universitetets ændrede rolle i samfundet, og en måde hvorpå man kan realisere det potentiale, der er iboende i denne universitetets forandrede værensform.

Dette sker ved at beskrive, hvordan universitetets 'væren' er under stadig forandring fra, hvad blandt andre Shumar, 1997, Barnett, 2011, Hansen, 2010 og Barnett \& Bengtsen, 2017 kalder modus 1 universitetet frem mod nutidens fremherskende modus 2 universitet og frem videre frem mod morgendagens modus 3 universitet. Denne beskrivelse af universitetets forandrede mandat og værensform, der ligger til grund for det didaktiske formede, sker gennem inddragelse Heideggers begreb om 'væren' og det 'værende' (Heidegger, 1926) for derigennem at begribe universitetet som et væsen under stadig forandring, og hvordan denne forandring også virker tilbage på undervisningens rolle og muligheder. Det er på baggrund af modus 3 universitetets fremkomst og værensform, at didaktiske refleksioner, pædagogisk værdigrundlag og læringsdesignmæssige valg, der ligger til grund for kurset Design: teori, metode og praksis og etableringen af undervisningsbaserede forskningskollektiver, skal forstås.

Universitetet, og dermed også universitetsundervisningen, har gennem tiden gennemgået store transformationer, der har bevæget universitet og undervisning gennem forskellige former for 'væren' og eksistensgrundlag. Gennem disse 'værenstransformationer' har universitet og under- 
visning forandret sig, både hvad angår dets interne iboende formål og eksterne relationer til omverden. I det følgende vil vi nærmere beskrive disse 3 'værenstransformationer' for at forstå, hvordan undervisningsdesign for akademiske partnerskaber og undervisningsbaserede forskningskollektiver konkret forholder sig til morgendagens modus 3 universitet.

\section{Elfenbenstårnet: Modus 1 universitetet}

Universitetet kan i dets tidlige eksistens, ifølge Barnett, beskrives som 'the metaphysical university' (Barnett, 2011). Universitetets 'værensform' er her ofte blevet illustreret gennem at fremstille universitetet som et 'elfenbenstårn.' I elfenbenstårnet blev viden opbevaret og bevogtet bag lukkede porte i et selvopretholdende økosystem. Elfenbenstårnets beboere havde til opgave at videreføre viden fra generation til generation og fra universitet til samfund. Viden var universel og havde egenværdi og eksisterede inden for en lukket geografi og en lukket ontologi (Barnett, 2011; Barnett \& Bengtsen, 2017).

Modus 1 universitetet havde selv magten over viden og kunne afgøre, hvilken viden og hvilke kompetencer det omkringliggende samfund og befolkningen havde brug for (Barnett, 2011, s. 18). Forholdet til omverden foregik som en transmission af viden fra universitet til samfund, hvor 'de vidende' formede den studerendes og samfundets tænkning gennem at fortælle dem, hvad de havde brug for at vide. Det var universitetet, der afgjorde, hvornår man talte som tilstrækkeligt og ordentligt (ud)dannet. Således er uddannelse i elfenbenstårnet en overdragelse af viden og en dannelse, der lukker sig om sig selv og er et indadvendt selvopretholdende økosystem med fokus på opbyggelse og overdragelse af forskning og universel viden. Dette var et universitet, hvis formål var 'for-sig-selv' (Barnett, 2011).

Som institution er modus 1 universitetet således et elfenbenstårn opbygget af viden, som gennem uddannelse og undervisning transmitteres fra tårn til studerende gennem en undervisers forelæsninger eller indføringer. Når viden er blevet reproduceret fra tårn til studerende, kan den studerende tage sit tårn af viden med sig og virke på dannede måder blandt befolkningen og $\mathrm{i}$ samfundet (Barnett, 2011, s. 11-12).

Selvom modus 1 universitetet i høj grad er en 'værensform', der ikke længere er mulig for universitetet som sådan, finder man stadigvæk efterbilleder og afarter af denne form for 'væren', både i form af kurser der til stadighed praktiseres efter modus 1-tankegangen og som egentlig grundforskning, der ikke synes at have nogen umiddelbar nytteværdi. Det skal altså ikke forstås sådan, at universitetets modus 1-værensform er arkaisk eller bagstræberisk, men snarere sådan, at det er en værensform, der ikke længere er mulig for det gængse universitet at praktisere i dag (medmindre man som fx Oxford Universitet har midlerne og mulighederne for at bevare sig selv som elfenbenstårn). For det almindelige universitet, og for alle danske universiteter, gælder, at elfenbenstårnet som værensform ikke længere er muligt, idet de er blevet transformeret til modus 2 universiteter, hvor rollerne og magtforholdet mellem samfund og universitet i høj grad er blevet byttet om. Elfenbenstårnets døre er blevet sparket ind, og samfundet er trængt ind i alle kroge af universitet, uddannelse og undervisning.

\section{Fabrikken: Modus 2 universitetet}

I dag har universitetet mange forskellige værensformer. Barnett (2011) benævner bl.a. 'the scientific university', 'the entrepreneurial university' og 'the corporate university' som udbredte værensformer for nutidens universitet. På tværs af disse forskelligartede universitetsformer er 
der dog træk, der synes at gå igen. Det er disse fællesstræk, som tilsammen kan siges at udgøre modus 2 universitetets kernetræk.

I stedet for universitetet som elfenbenstårn har vi således fået universitetet som fabrik. Her anskues universitetet som producent af fremtidens arbejdskraft. På fabrikken er det ikke længere universitetet, der ejer og overfører viden, men derimod samfundet, der er bestemmende i forhold til, hvilken viden, kompetencer, forskning og undervisning der er brug for. Effektivitet, output og samfundsmæssig nytteværdi står centralt, og universitetets opgave er således i høj grad at være leverand $\varnothing r$ af det, som samfundet efterspørger.

I dag finder universitet, undervisere og forskere sig selv i en situation, hvor de er frataget ejerskabet og definitionsretten til, hvad der tæller som relevant viden og nødvendig og tilstrækkelig (ud)dannelse. Fabrikken har ikke magten over sin egen skæbne, det er et spørgsmål om udbud og efterspørgsel, og dets relevans måles på evnen til gennem effektiv undervisning at producere fremtidens arbejdende samfundsborgere, der på deres side kan skabe socioøkonomisk værdi og innovation til gavn for samfundet. Dette er i tråd med, hvad Shumar (1997) kalder det neoliberalistiske universitetsstyre eller 'the corporate university', der vokser ud af bl.a. 'new economy', 'new capitalism' og 'knowledge economy' (Selwyn, 2014; Fairclough, 2003; Simpson \& Mayr, 2010; Wright, 2016; Shumar, 1997).

Viden er en handelsvare, der skal hjælpe samfundet med at holde sig konkurrencedygtigt, og det er universitetets opgave at levere varen gennem at producere de rigtige studerende med de rigtige kompetencer til de rigtige jobs. Undervisere holdes på deres side ansvarlige for produktionen, og at den foregår i et passende tempo, så værdi ikke går tabt. Dette kommer også tydeligt til udtryk i OECD-rapporten 'The Knowledge-based Economy' fra 1996.

The OECD economies are increasingly based on knowledge and information. Knowledge is now recognised as the driver of productivity and economic growth, leading to a new focus on the role of information, technology and learning in economic performance. The term "knowledge-based economy" stems from this fuller recognition of the place of knowledge and technology in modern OECD economies. (OECD, 1996)

Denne transformation af universitetets væren finder måske sit tydeligste udtryk på, hvad Barnett (2011) kalder 'det entreprenørielle universitetet.' Denne værensform er også forædlet på de danske gennem universiteter gennem de seneste år i form af reformer, omstruktureringer m.m., der sammenlagt har fået universitetet til at fokusere på at uddanne udadtil snarere end at sikre viden indadtil gennem at være færdighedsorienteret, samfundsnyttig og omstillingsparat. Universitetet er blevet en politisk styret fabrik for nyttig viden, der kan hjælpe samfundet med at løse de problemer og behov, som er fremherskende og presserende netop nu.

Denne værensform vokser ydermere ud af en fremherskende global tendens til, at universiteterne i stadig stigende grad er blevet industrialiserede og professionaliserede og har etableret afdelinger, der beskæftiger sig med branding, virksomhedsstrategier, acceleratorer, inkubatorer m.m. (Barnett, 2011, s. 50-51).

Inden for de seneste år er der dog fremkommet en spirende modreaktion på denne værensform (ligesom fabrikken som værensform kan siges at være en modreaktion på elfenbenstårnet). 
Hvor der på modus 1 universitetet foregik en envejs-transmission af viden fra universitet til samfund, og der på modus 2 universitetet ligeledes foregår en envejs-transmission af videnskrav fra samfund til universitet, ser vi nu begyndende tegn på et mere tosidet og dialogisk forhold, for så vidt angår relationen mellem universitet og samfund. Hvad vi andetsteds har kaldt for fremkomsten af akademisk medborgerskab - det forhold, at universitet, forsker, underviser og studerende indgår i dialog med hinanden og med verden gennem at være medborger og aktør i samfundet på akademiske måder (Nørgård \& Bengtsen, 2016).

\section{Medborgerhuset: Modus 3 universitetet}

På modus 3 universitetet indgår universitet og samfund, undervisere, forskere, studerende og medborgere sammen i kritisk-kreative dialoger og partnerskaber med det formål sammen at skabe fremtidig viden og samfundsværdi, der rækker ud over umiddelbar nytteværdi, problemløsning og efterspørgsel.

Modus 3 universitetet adskiller sig således fra modus 1 og 2 universitetet, i og med at hverken samfund eller universitet har definitionsmagten eller dikterer dagsordenen - universitetets værensform er her både geografisk og ontologisk åben - idet de indgår i samtaler og samarbejder med hinanden med det formål at sam-skabe viden for en fremtidig endnu ukendt omverden. Universitet og omverden integreres på den måde i hinanden, de bliver en del af samme økologi og står i hinandens tjeneste.

Her vedbliver undervisningslokale, kontor og campus med at være åbent som på modus 2 universitetet, ikke som gennembrudt bolværk, men som åbent medborgerhus, hvor samfund og universitet, borgere, undervisere, forskere og studerende kan mødes, tænke og arbejde sammen. På sin vis kan modus 3 universitetet ses som det dydige universitets genkomst (Nixon, 2008), hvor samfundsværdi, menneskeligt værd og akademisk dannelse står i centrum af de dialoger, der pågår i medborgerhuset. Således beskriver Nørgård og Bengtsen (2016) et 'væren-iverden' for fremtidens universitetet, hvor der sker en integration mellem universitetet og omverden gennem kritisk dialog og interaktion imellem disse, der får et tredje sted til at træde frem (Nørgård \& Bengtsen, 2016, s. 10-13).

Modus 3 universitetet kan også begribes termen 'the ecological university' (Barnett, 2011, s. 141-151). Medborgerhuset er således et universitet, der bekymrer sig om og engagerer sig i sin omverden, hvilket fordrer en respektfuld og gensidig integration af universitet i omverden og omverden i universitetet (Barnett, 2011, s. 143-144).

Det $\varnothing$ kologiske universitet befinder sig ifølge Barnett i et netværk med sin omverden og bekymrer sig om 'den anden' i dette netværk (Barnett, 2011). Men modus 3 universitetet fordrer også, at omverdenen bekymrer sig om og engagerer sig i universitetet. Med modus 3 universitetet sker således en 'dobbelt-bevægelse' mellem omverden og universitet, der fra universitetets side materialiserer sig som en invitation til studerende, borgere, medarbejdere og andre til at 'deltage $\mathrm{i}$ universitetets ide' (Ossa-Richardson, 2014, s. 154).

Dette engagement og denne dialog muliggøres dels gennem at modsætte sig, at universitetet resignerer og hæver vindebroen som modreaktion på modus 2 universitetet, dels gennem at modsætte sig presset mod, at markedsliggørelse, nyttetænkning og umiddelbar anvendelig viden og færdigheder oversvømmer universitetet. Gennem denne dobbelt-bevægelse holdes universitetet på en gang åbent og sammen gennem forskeres, underviseres, studerendes, borgeres og 
medarbejderes dialog og deltagelse i det samfundsintegrerede og samfundsintegrerende universitet.

Medborgerhuset bevæger således universitetets værensform væk fra de socioøkonomiske og 'nyttige' relationer, som gjorde sig gældende for modus 2 universitetet, hvor universitetets relation til omverden var defineret af udefrakommende forhold. Modus 3 universitetet er i højere grad bygget på, hvad Polanyi kalder substantivistiske relationer, hvor sociale og menneskelige relationer og værdier går forud for økonomiske rationaler (Polanyi, 2001, s. 59-70). Modus 3 universitetet opnår dette gennem at være et medborgerhus, mødested eller kooperativ for kritisk-kreative dialoger og partnerskaber med omverdenen. På sin vis kan modus 3 universitetet siges at bygge på gamle principper for andelsbevægelsen, der stammer helt tilbage fra 1844 med de såkaldte 'Rochdale Principles'. Disse 7 principper beskriver kernetræk for kooperativer og kan dermed også give indsigt i nogle af grundprincipperne for modus 3 universiteter:

1. Frit og ligeværdigt medlemskab: Kooperativer er frivillige organisationer, der er åbne for alle, som vil benytte sig af deres ydelser, og som er villige til at bidrage aktivt til udviklingen af organisationen.

2. Demokratisk medlemskontrol: Kooperativer er demokratiske organisationer, der kontrolleres af sine medlemmer. Medlemmerne deltager aktivt $\mathrm{i}$ at fastlægge politikker og træffe beslutninger.

3. Medlemmernes økonomiske deltagelse: Medlemmerne bidrager på en retfærdig måde til og kontrollerer kooperativets økonomi på demokratisk vis. Hele eller dele af den indskudte kapital tilhører kooperativets fællesformue. Medlemmerne modtager sædvanligvis kun begrænset udbytte for deres bidrag til kapitalen, som er betingelsen for deres medlemskab.

4. Selvstændighed og uafhængighed: Kooperative virksomheder er selvstændige og uafhængige organisationer, som styres af medlemmerne. Indgås der aftaler med andre organisationer, herunder offentlige myndigheder, eller rejses der kapital fra eksterne investorer, sker det på vilkår, der sikrer medlemmerne demokratisk styring og kontrol og bevarer kooperativets uafhængighed og handlefrihed.

5. Uddannelse, oplysning og information: Kooperative virksomheder stiller uddannelse og viden til rådighed for medlemmerne, valgte repræsentanter, ledere og ansatte, sådan at de kan bidrage effektivt til udviklingen af deres virksomheder.

6. Samarbejde mellem kooperativer: Kooperative virksomheder varetager medlemmernes interesser og fremmer den kooperative bevægelse mest effektivt igennem samarbejde i lokale, regionale, nationale og internationale organisationer.

7. Interesse for samfundet: Kooperative virksomheder arbejder for en bæredygtig udvikling af lokalsamfundet gennem politikker vedtaget af medlemmerne. (Kooperative principper: https://kooperationen.dk/kooperativer/kooperative-principper/)

I centrum af modus 3 universitetets værensform står således de kooperative principper og partnerskabet med omverdenen. Her anses også de studerende som ligeværdige partnere og medskabere af universitetets ide gennem undervisning, forskning og omverdensinteraktion og integration. En konkretisering af denne tænkning kan findes hos fx University College London $\mathrm{i}$ deres uddannelsesstrategi for 2016-2021, som de har kaldt for A Connected Curriculum for 
Higher Education (Fung, 2017). Connected Curriculum er et tydeligt eksempel på modus 3 universitetet, idet der fokuseres på:

- Undervisning, der sigter mod, at de studerende er forskningsproducerende allerede fra 1. semester (hvad UCL kalder for en 'research throughline')

- Undervisning, der inviterer de studerende til at være forskere på universitetet og deltagere i nationale og internationale forskningsnetværk på lige fod med universitetets $\varnothing$ vrige forskere

- Undervisning, der muliggør, at studerende er aktører i og partnere med omverdenen

- Undervisning, der forbinder studerende og ansatte på universitetet i ligeværdige partnerskaber

- Undervisning, der skaber partnerskaber på tværs af discipliner og fagligheder

- Undervisning, der udmønter sig i udvikling af de studerendes akademiske medborgerskab i form af akademiske produkter, der rækker ud over undervisningslokalet og campus (Fung, 2017)

Ovenstående konceptualisering af modus 3 universitetet som medborgerhus for nye partnerskaber udgør ligeledes også rationale og fundament for udviklingen af undervisningsbaserede forskningskollektiver som didaktisk format, der vil blive præsenteret nedenfor.

\section{Undervisningsdesignet didaktiske format: Forskningsproducerende undervisning og undervisningsbaserede forskningskollektiver}

Med udgangspunkt i gennemgangen af universitetets modus 1, 2 og 3 som værensform, vil dette afsnit fokusere på, hvorledes man med afsæt i modus 3 universitetet kan rekonfigurere konceptualiseringen af undervisning, studerende, forskning og omverden. Nærmere bestemt fokuserer afsnittet på undervisningsbaserede forskningskollektiver som didaktisk format i krydsfeltet mellem forskningsproducerende undervisning og akademisk medborgerskab og partnerskaber. Netop dette krydsfelt kan anskues som et potentielt væksthus for didaktiske formater for universitetet som medborgerhus. Her forstås partnerskab som:

a process of student engagement, understood as staff and students learning and working together to foster engaged student learning and engaging learning and teaching enhancement ... It is a way of doing things, rather than an outcome in itself. (Healey et al., 2014, s. 7)

Endvidere beskriver Matthews i "Students as partners as the future of student engagement" (2016) studerendes akademiske partnerskaber som afgørende for de studerendes (ud)dannelse på modus 3 universitetet, hvor studerende italesættes og indtænkes som samarbejdende partnere i såvel undervisning som forskning og som havende en naturlig, autentisk og anerkendt plads i universitetets undervisnings- og forskningsnetværk og -aktiviteter (Matthews, 2016).

Disse dialogiske akademiske partnerskaber inden for universitetet samtænkes dernæst med akademisk medborgerskab, som det udfolder sig i dialog med omverdenen på en sådan måde, at universitet, omverden og livsverden væves sammen og folder sig ud inden for den samme økologi: 
Having academic citizenship implies the formation of public place within the university and academic place within society. This is done authentically when the university offers itself as means and springboard for social issues and activities in order for them to become critically visible and aware of themselves and the inherent opportunities within them, rather than when the university offers to solve or judge the challenges within society. However, 'means' does not in this context connote a passive and indifferent offering of oneself (as the idea of 'service' might critically be under- stood), but rather an engaged, responsible and dialogical solicitude. [...] That entails designing universities that allow for openness, dialogue, mutual integration, joint responsibility and care - a placeful university for academic citizenship beyond the campus. (Nørgård \& Bengtsen, 2016, s. 14)

Afg $\varnothing$ rende for udvikling af modus 3-undervisning gennem partnerskaber og akademisk medborgerskab er underviseres og universitetets evne til at gentænke deres undervisnings- og uddannelsespraksis for at bevæge sig mod former, der i højere grad arbejder intentionelt med at etablere dialogiske partnerskaber, samskabelse, akademisk medborgerskab, forskningsproducerende studerende og kritisk-kreativt ligeværdigt engagement mellem undervisere, forskere og studerende samt universitet og omverden.

Én måde at arbejde intentionelt med dette på er gennem udformningen af undervisningsbaserede forskningskollektiver $i$ et nexus mellem undervisning, forskning og omverden på modus 3 universitetet.

Oprettelse og udvikling af undervisningsbaserede forskningskollektiver sker gennem, hvad Fielding kalder 'radical collegiality': "a collegiality constitutive of a professionalism commensurate with the move towards a more dialogic form of democracy. Here teachers learn not only with and from each other, from parents [or researchers] and from their community, but also, and more particularly, from their students" (Fielding, 2001, s. 130). Fielding fremhæver her, især at partnerskaberne, for at være produktive og anerkendende, $b \varnothing r$ :

- fokusere på processer og projekter, der er valgt og drevet af de studerende, men sammen med undervisere og forskere.

- være baseret på ekspertise og perspektiver, som såvel studerende, forskere som undervisere bringer med sig ind i kollektivet, og anerkende deres forskellige former og forudsætninger.

- $\quad$ æære dialogisk og bevæge sig fra transmission af viden og monologiske undervisnings- og læringsformer mod samtale, samskabelse og samvær mellem studerende, forskere og undervisere samt undervisningsinstitution og omverden.

- fokusere på studerende som forskere eller forskerteams i egne forskningsprojekter med undervisere og forskere som deltagere $i$ stedet for at anskue de studerende som deltagere, medforskere eller forskningsassistenter $\mathrm{i}$ underviseres eller forskeres egne projekter.

- indtænke forskningsnetværk, omverdenskommunikation og vidensdistribution i partnerskabet, hvor undervisere og forskere åbner egne netværk og partnerskaber for de studerende, ligesom de studerende etablerer og udvikler egne netværk og partnerskaber med det formål at få forskningsresultaterne ud til de partnere, de vedrører, samt gøre dem offentligt tilgængelige (Fielding, 2001, s. 129-133). 
Bland og Atweh understreger endvidere vigtigheden af, at de studerende ikke bliver assistenter $\mathrm{i}$, men er ejere af de forskningsproducerende processer, idet de peger på en bevægelse fra

... mere student consultation to student involvement in research activities. Here, we take this one step further [...] positioning the students as principal researchers in the PAR collaboration and creating an environment in which they feel comfortable expressing their ideas and opinions. Secondly, the projects present challenges to student researchers, such as presenting and discussing their findings at conferences and through publication. (Bland \& Atweh, 2007, s. 346)

Ovenstående understreger således vigtigheden af, at etableringen af dialogiske og demokratiske forskningskollektiver er en forudsætning for forskningsproducerende undervisning. Hermed må underviserens rolle gentænkes fra leverand $\varnothing r$ af viden (forskningsinformeret og forskningsbaseret undervisning) til at blive medforsker og deltager gennem at engagere sig i og blive en del af de studerendes forskningsprojekter i forskningskollektivet i stedet for den anden vej rundt:

Co-creating, co-producing, co-learning, co-designing, co-developing, co-researching, and co-inquiring involve sharing power and an openness to new ways of working and learning together and, hence, challenges traditional models of HE relationships. (Haley, Flint \& Harrington, 2016, s. 9)

En yderligere pointe i forhold til udformningen af didaktiske formater for modus 3 undervisning er, at de studerendes partnerskaber i forskningskollektivet ikke kun indgås internt på universitetet, men i lige så høj grad også indgås med omverdenen, idet de i partnerskab med universitetet er i undersøgende dialog og partnerskab MED samfundet. De studerende er således ikke inddæmmet på universitetet, hvor de producerer viden, men er i interaktion med samfundet som akademiske medborgere.

Undervisningsbaserede forskningskollektiver som didaktisk format sigter mod at skabe processer, der underst $\varnothing$ tter og realiserer disse dimensioner, idet de studerende ikke overlades til at agere forskere eller akademiske medborgere på egen hånd, men har såvel underviser som mentor som undervisningens ramme og rum som katalysator for dette.

Overordnet set samtænker undervisningsbaserede forskningskollektiver partnerskaber, akademisk medborgerskab og forskningsproducerende undervisning i fors $\varnothing$ get på at udfærdige et didaktisk format for modus 3 universitetet. Det følgende afsnit vil beskrive det didaktiske format sådan, som det udfolder sig og opleves i praksis for de studerende, ligesom det vil præsentere de studerendes proces og produkter i det undervisningsbaserede forskningskollektiv, de var en del af.

\section{Undervisningsdesignet $i$ praksis: At være studerende $i$ undervisningsbaserede forskningskollektiver}

I det følgende præsenteres artiklens case med udgangspunkt i 20 ECTS-kurset Design: teori, metode \& praksis, sådan som det udfoldede sig som undervisningsbaseret forskningskollektiv. Casen er beskrevet ud fra det i metodeafsnittet præsenterede empiriske grundlag med særligt fokus på studerendes oplevelser af forløbet og læner sig op ad analyse af både studenterprodukter, billeder, feltnoter og refleksive feltnoter. 
Casebeskrivelsen rækker ud over det konkrete semester, hvor faget blev afholdt, for også at reflektere, hvordan partnerskaber og akademiske partnerskaber danner grundlag for forskningsprocesser og -produkter ud over kurset selv. Casen forløber således sammenlagt over 1,5 år med kurset som begyndelsespunkt.

Casen fokuserer på en af kursets projektgrupper, der var involveret i et forskningsprojekt omkring MOOCs (Massively Open Online Courses); nærmere bestemt MOOC'en Blended Learning Essentials udbudt af FutureLearn. Forskningsprojektet omkring MOOC'en, blev udført af en gruppe på i alt seks studerende, der i fællesskab og med underviseren som partner og mentor udførte en netnografi (Kozinets, 2015) og research through design af MOOC'en. I netnografien foretog de seks gruppemedlemmer deltagerobservation fordelt på forskellige forskerroller, idet nogle var deltagere, nogle observerende deltagere og nogle observat $\varnothing$ rer. Projektgruppens konkrete forskningsdesign, -projekt og -resultater er nærmere beskrevet i Mathiesen, Nedergaard \& Nørgård, 2016.

På baggrund af projektgruppens unders $\varnothing$ gelsesdesign og netnografiske feltarbejde i MOOC'en blev der udført dokumentanalyse af feltnoter, og MOOC'ens kommunikation blev kategoriseret og kodet. Analyse og kodning af MOOC'ens kommunikation, interaktioner og deltagerobservationer dannede dernæst grundlag for den efterfølgende research through design-proces (Dalsgaard, 2010). På baggrund af projektets samlede undersøgelser og fund fandt gruppen, at selv MOOCs der eksplicit sigter mod skabelse af kommunikation og fællesskab, alligevel kan mangle tilstedeværelse af samtale, samarbejde og samvær. Denne mangel fors øgte projektgruppen efterfølgende at svare på gennem at opstille et alternativt MOOC-design der i højere grad understøttede disse kvaliteter, og dette alternativ fungerede sammen med eksamensopgaver og efterfølgende forskningspublikation som udkommet af projektgruppens research through design.

En væsentlig indsigt, der trådte frem på baggrund af projektgruppens arbejde i et undervisningsbaseret forskningskollektiv med ansvar for en reel forskningsproces ind $i$ en faktisk kontekst uden for universitetet, var nødvendigheden af, at underviser kontinuerligt fungerede som vejledende mentor i forhold til, var tilstedeværende som partner i, samt indgik i kritiske dialoger med projektgruppen. Denne forsknings-mentor-rolle var afgørende for at modvirke de studerendes oplevelser af frustration, forvirring og usikkerhed, der opstod i forskningskollektivet, når en velkendt holdundervisningsform transformeres fra vidensoverdragende og forskningsbaseret undervisning til vidensgenererende og forskningsproducerende kollektiver.

Selvom de studerende således var ejere af egne forskningsprojekter og producenter af egne forskningsprodukter, var underviseren stadigvæk tilstedeværende og engageret i kollektivet og grupperne gennem ugentlige vejledninger, fælles udforskninger og analyser af data og fund samt kritisk feedback på og review af skitser til forskningsprodukter. En af kursets studerende forklarer det på denne måde:

Igennem de forskellige faser fik man som studerende lov til at indtræde i forskellige roller, både som studerende, men til dels også som forsker. I semesterprojektet fik vi en forsmag på, hvordan man agere som forsker ved at udføre en feltundersøgelse på MOOC'en 'Blended Learning Essentials'. Som studerende kan det være enormt skræmmende at blive smidt ud i en kontekst, hvor man pludselig på egen hånd skal udføre en feltunders $\varnothing-$ gelse, her var det enormt vigtigt at have en underviser, der støttede en, da man på egen 
hånd hurtigt kan komme ud på for dybt vand. (Studerende på Design: teori, metode og praksis, IT-Didaktisk Design, Aarhus Universitet)

Research through design-processen, som de studerende gennemløb i kurset, var opdelt i en række faser med hver deres forskningsintention.

- I processens første udforskende fase unders $\varnothing$ gte de studerende en given kontekst og indsamlede empirisk materiale.

- Herefter kodede, analyserede og fortolkede de det indsamlede materiale med henblik på at afdække problemfelter, der kunne lægges til grund for aktionsforskning i form af redesign. Et centralt problemfelt viste sig i den pågældende projektgruppe at være en mangel på egentlig dialog i den unders $\varnothing$ gte MOOC.

- Dette problemfelt afdækket gennem den analytiske fase blev dernæst lagt til grund for en problemløsningsfase, hvor forskellige ideer til løsning af problemet blev genereret på baggrund af et udformet empirisk og teoretisk rammeværk.

- På baggrund af genererede analytiske indsigter og et teoretisk rammeværk omkring dialog og online-læring udformedes dernæst et designforslag for inddragelse af synkron kommunikation i MOOC'en.

- Designforslagets hypotese testes i form af forskningsbaserede ideer og prototyper, der efterfølgende blev præsenteret og diskuteret på konferencen Internet Week Denmark.

- Slutteligt fulgte integrationsfasen, hvor viden og resultater fra den analysefase og problemløsningsfase samles og formidles i form af de studerendes eksamensopgaver, designprodukter, academic posters og forskningspublikationer.

En studerende oplever forskningsprocessen således:

Ud fra feltundersøgelsen blev designprocessen i høj grad en måde, hvorpå vi fik mulighed for at give brugerne af MOOC'en en stemme og sætte fokus på manglende dialog $i$ MOOC'en. Dette fremlagde vi på Dokk1, hvor vi fik mulighed for at gå i dialog med interesserede fra hele samfundet omkring dialog i MOOCs. Dette var som studerende spændende, fordi vi fik mulighed for at fremlægge resultaterne af vores undersøgelse som forskere, undersøgelsen fik derved en værdi, hvor det ikke blot var en 'øvelse', men en 'rigtig' undersøgelse. (Studerende på Design: teori, metode og praksis, IT-Didaktisk Design, Aarhus Universitet) 


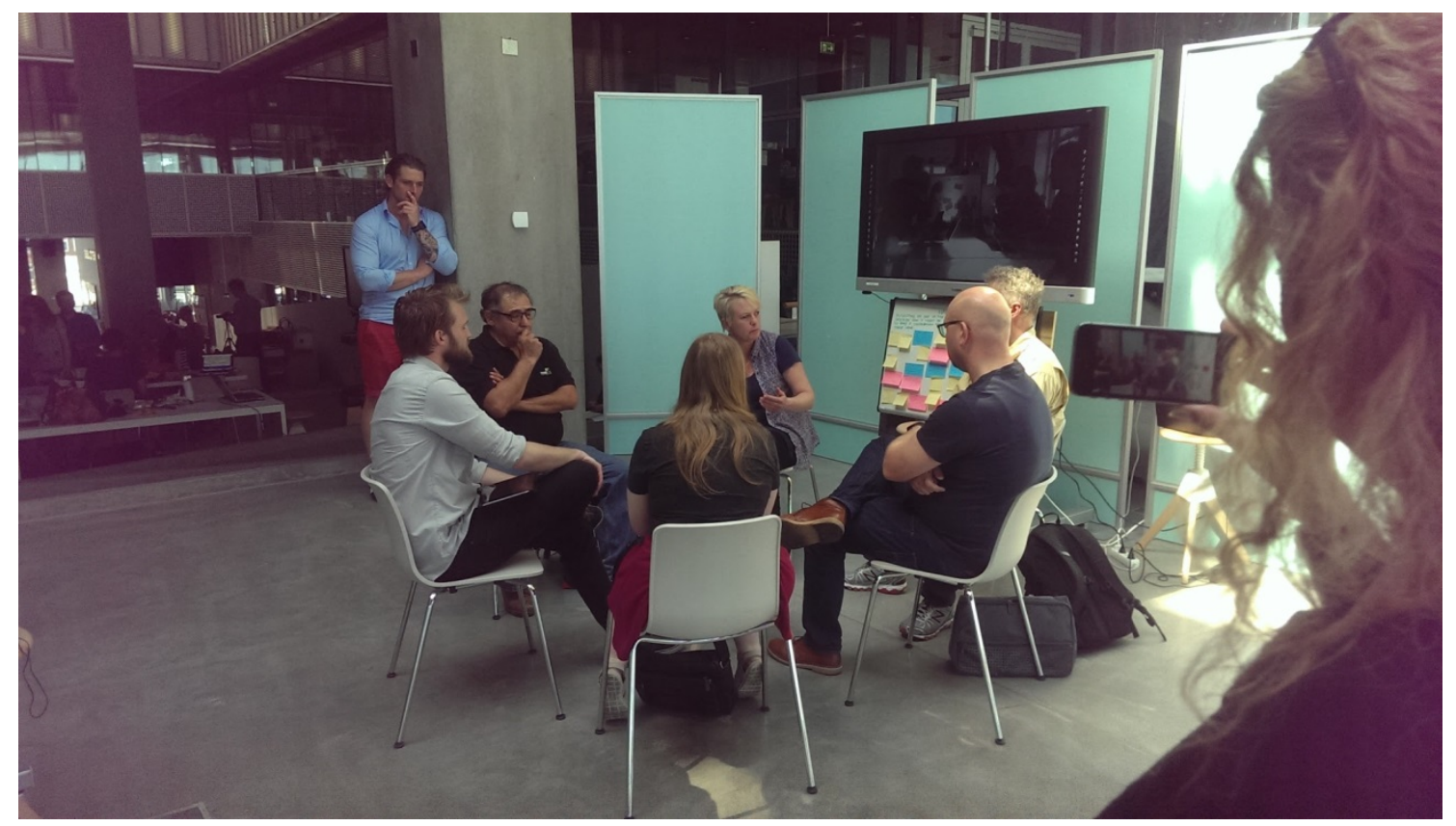

Figur 1: Fra projektgruppens præsentation til Internet Week Denmark på Dokk1 i Aarhus, hvor de diskuterede forskningsprojektets fund og deres bud på redesign af MOOCs, så de i højere grad inviterer til dialog.

Som afslutning på analyse- og problemløsningsfasen afholdt alle projektgrupper i forskningskollektivet præsentationer, designudstilling og workshops på Internet Week Denmark. Her blev forskellige elementer af deres forskningsprojekter formidlet til offentligheden, projektpartnere og andre interessenter gennem et studenterdrevet forskningssymposium for publikum i det offentlige rum, workshops med forskningsprojekternes målgrupper samt en udstilling med akademiske posters, videopitches og designprototyper, der fremviste og diskuterede fund.

Denne del af den forskningsproducerende undervisning var i høj grad kulminationen på den dimension, der omhandlede akademisk medborgerskab. Omverden blev for MOOC-gruppen inddraget $\mathrm{i}$ forskningsprojektet og -processen som dialogpartnere og medskabere af det endelige design. Efter Internet Week Denmark ændredes fokus i forskningskollektivet sig fra akademisk medborgerskab til forskerpartnerskaber, hvor deltagere i grupperne sammenskrev empirisk proces, teoretisk viden, omverdensinteraktion og forskningsprodukter. Her opdelte forskningskollektivets grupper sig i mindre skriveteams, der sammen udfærdigede deres traditionelle eksamensopgaver på baggrund af gruppernes forskningsprocesser.

Efter kursets afslutning blev der etableret et forskerpartnerskab mellem to af de studerende fra gruppen og underviseren med det formål at skrive en forskningsartikel til tidsskriftet Læring og Medier med henblik på at formidle de vigtigste indsigter og fund, der var gjort gennem forskningsprojektet. Udfærdigelsen af artiklen blev drevet af de studerende som første- og andenforfatter, hvor underviseren var med til at vejlede den akademiske proces, give review ift. til den akademiske genre og tilrette ift. formalia og skrivestil.

For at anerkende de studerendes ejerskab ift. forskningsproces og indhold $\mathrm{i}$ artiklen i det akademiske partnerskab blev underviseren, der er ansat som lektor på Aarhus Universitet, således skrevet på som artiklens tredjeforfatter. Forfattelse og review af artikel blandt de tre forfattere forløb over det efterfølgende semester parallelt med de to studerendes normale kurser og udgjorde derfor en ekstra og ekstern arbejdsbyrde. 
At skrive såvel eksamensopgave som forskningsartikel blev af den studerende omtalt således:

Eksamensopgaven fungerede som en evaluering af vores designproces, her var vi i høj grad tilbage i studenterrollen, hvor vi skulle præstere en traditionel akademisk opgaveaflevering. Efter semesterprojektet fik vi mulighed for $i$ endnu højere grad at indtræde i forskerrollen, hvor vi sammen med vores underviser skrev en artikel baseret på vores semesterprojekt til Læring og Medier. Forløbet efter semesterprojektet udgjorde en ekstra arbejdsbyrde ved siden af vores normale studie, til gengæld var det enormt fedt at blive bekræftet $i$, at det arbejde, vi præsterede, havde forskningsmæssig værdi, ved at vores artikel blev godkendt i dobbelt-blind-peer-review. (Studerende på Design: teori, metode og praksis, IT-Didaktisk Design, Aarhus Universitet)

Efter den endelige forskningsartikel var afleveret og endeligt godkendt, fortsatte en af de to studerende, der havde skrevet artiklen, det akademiske partnerskab med underviseren, idet der blev indleveret et fælles paper til Dansk Universitetspædagogisk Netværk-konferencen.

Dette paper havde i højere grad fokus på kursets akademiske processer, læringsoplevelser og forskningskollektiver. Paperet bar titlen "Med MOOCs som case: Studerendes videnskabelige processer og produkter i undervisningsbaserede forskningskollektiver" og blev præsenteret til DUN-konferencen 2017 der havde temaet Students - co-creators, co-teachers, co-researchers.

Til konferencen præsenterede studerende og underviser paperet sammen, med fokus på hvordan kursets proces kunne ses som undervisningsbaserede forskningskollektiver, hvor studerende inddrages ikke blot som co-creators eller co-researchers, men som skabere og ejere af egne forskningsprojekter og -produkter.

Sammenlagt har processen for de studerende i det undervisningsbaserede forskningskollektiv $\mathrm{i}$ høj grad taget form af research through design-processer, der har ledt frem mod forskningsresultater og -produkter som illustreret med udgangspunkt i Yishay Mors model nedenfor:

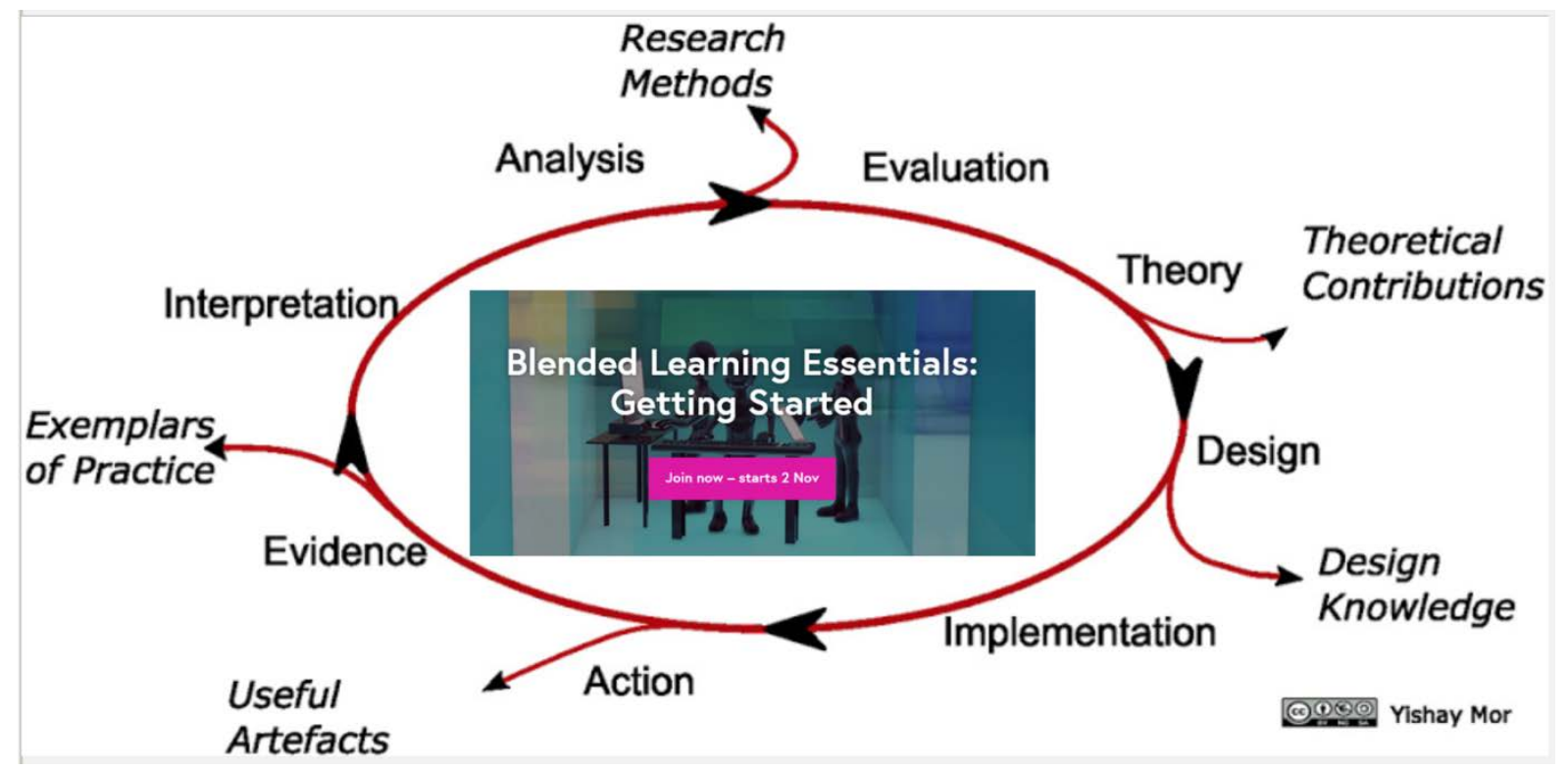

Figur 2: Model for projektgruppens research through design proces omkring MOOC'en Blended Learning Essentials, som den fandt sted $i$ det undervisningsbaserede forskningskollektiv (model baseret på Mor, 2009). 
Som omdrejningspunkt i forskningsprocessen står MOOC'en Blended Learning Essentials. Igennem universitetskursus, præsentation for offentligheden, medforskere og interessenter på Internet Week Denmark, forskningsartikel og konferencepræsentation på DUN-konferencen blev research through design-processen gennemløbet flere gange, hvilket resulterede i flere forskellige forskningsprodukter -typer og -processer samt en dybere og mere nuanceret forståelse for forskning, både som felt, format og proces.

De forskningsprocesser og -produkter, som de studerende udfærdigede gennem dette længerevarende akademiske partnerskab, skabte en række modus 3-forbindelser både internt på universitetet og eksternt med omverden, hvor de studerende gennem det undervisningsbaserede forskningskollektiv indgik i reflekterede og dialogiske akademiske relationer med omverdenen. Disse relationer blev opretholdt og udbygget efterfølgende, hvor de studerende var med til at skabe en integration mellem omverden og universitetet (Nørgård \& Bengtsen, 2016).

Forskningsprocessen, som den udsprang af det undervisningsbaserede forskningskollektiv og udfoldede sig som akademisk medborgerskab og akademisk partnerskab, baserer sig sammenlagt på universitetet som medborgerhus manifesteret som en række modus 3-forbindelser illustreret i figur 3 nedenfor.
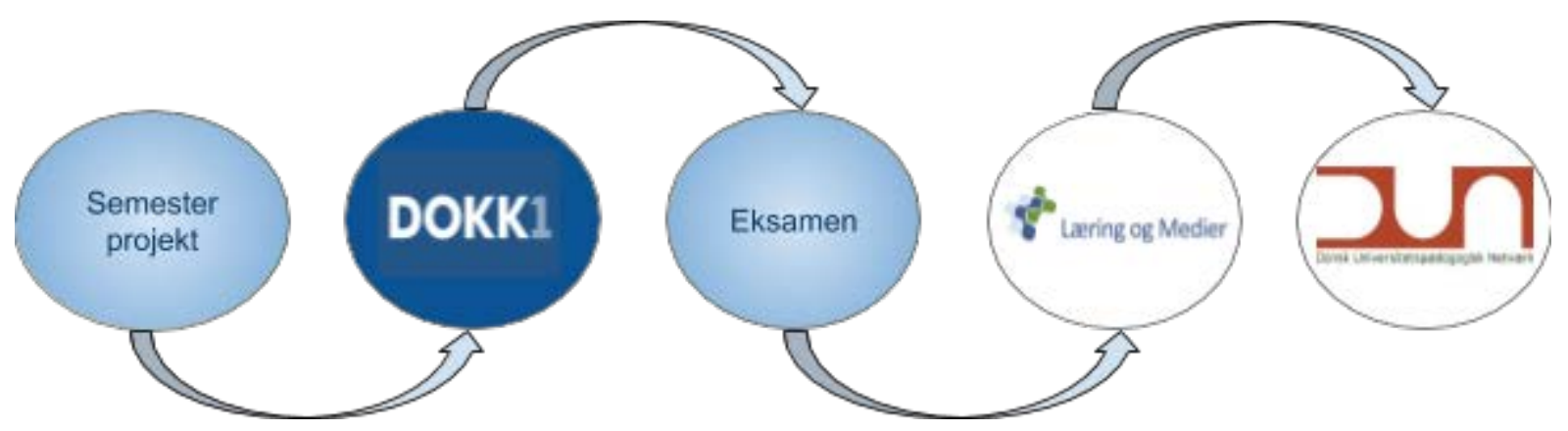

Figur 3: Længerevarende akademiske partnerskaber med udgangspunkt i undervisningsbaserede forskningskollektiver.

Her fremtræder både fremlæggelsen på Dokk1, artiklen i Læring og Medier samt paper og præsentation på DUN som modus 3-forbindelser, der er skabt gennem det akademiske partnerskab og har sit grundlag i det undervisningsbaserede forskningskollektiv. Som nævnt i afsnittet om metode er vores case eksemplarisk, og ikke alle studerende i faget indgik i en så langvarig proces som beskrevet ovenfor. Dog er det ikke kun studerende fra artiklens case, der efterfølgende har forfattet pointgivende forskningspublikationer, således også eksempelvis Rygaard \& Nørgård, under udgivelse. Ydermere deltog alle projektgrupper til Internet Week Denmark på Dokk1, hvor de afholdt en række workshops og præsenterede deres fund for omverden.

Denne inkorporation af modus 3-forbindelser og skabelse af forskningskollektiver kræver dog, at det er en integreret og obligatorisk del af undervisningen, da ikke alle studerende i udgangspunktet var af den opfattelse, at de havde tid eller kunne se meningen med dette. Denne omstændighed tydeligg $\varnothing \mathrm{r} n \varnothing$ dvendigheden af undervisningsdesign, der intentionelt indtænker modus 3-forbindelser, samt undervisere, der indgår på forpligtigende vis i forskningskollektivet og understøtter samt er i dialog omkring disse processer. Modus 3-forbindelser er altså ikke nogle, de studerende kan eller skal skabe på egen hånd eller have ansvaret for selv. De skal derimod udformes som intentionelle modus 3-undervisningsdesign og faciliteres af underviseren som en fuldgyldig partner og deltager i forskningskollektivet. 
Samlet valgte studerende fra to projektgrupper at indgive abstracts til forskningstidsskriftet $L æ-$ ring og Medier, og begge blev optaget. Men det var kun den ene af de to grupper, der fik udgivet deres artikel i sidste ende. De studerende fra den anden gruppe fik indsendt deres artikel til review, men da review kom retur, var de i gang med deres specialeproces og fandt dermed, at de hverken havde tid eller overskud til at gennemarbejde artiklen i overensstemmelse med det review, der kom retur.

Dette peger på, at ikke alle studerende har overskud til indgå i et akademisk partnerskab, der strækker sig ud over og ligger ved siden af deres normale undervisning. Her er det måske i højere grad nødvendigt at tænke holistisk i forhold til den uddannelse, de studerende er i gang med at tage, således at forskningsprodukter kan udvikles og udgives som en integreret del af uddannelsens forløb. Dette er også, hvad Fung i A Connected Curriculum for Higher Education (2017) benævner som en 'research throughline'. En sådan gennemgående forskningsproces kræver dog koordination på tværs af kurser, noget som ikke var muligt inden for det i artiklen omtalte kursus.

\section{Undervisningsdesignets principper: Undervisningsbaserede forskningskollektiver på modus 3 universitetet}

Som det også fremgår af ovenstående, så kræver udformningen af akademiske medborgerskab og partnerskaber, undervisningsbaserede forskningskollektiver og forskningsproducerende undervisning, at man anerkender og påtager sig det didaktiske og pædagogiske ansvar, også for dets skyggesider og etiske implikationer. Når man transformerer undervisning, så den målrettes modus 3 universitetet, er det vigtigt også at spørge ind til og arbejde intentionelt med, hvad Aaen \& Nørgård kalder 'shadowy siblings' (Aaen \& Nørgård, 2015); undervisningsdesignets erfarede slagskygger og bagsider.

Umiddelbart lovende formater som undervisningsbaserede forskningskollektiver, akademiske partnerskaber og forskningsproducerende undervisning indeholder ikke ensidigt positive oplevelser, udbytte eller erfaringer for de studerende, men også negative oplevelser, udkomme og erfaringer.

Gennem praktiseringen af undervisningsbaserede forskningskollektiver bliver det således tydeligt, at underviseren påtager sig det etiske ansvar for at føre de studerende ud på ukendt og dybt vand. Det er derfor vigtigt, at underviseren er tilstedeværende, engageret og i dialog med de studerende i disse processer, da der ellers er fare for, at de drukner, bliver stressede, eller processen bryder sammen.

Her må underviseren være villig til ikke blot at være til stede i rollen som traditionel holdunderviser, men også som mentor, der tilbyder at støtte dem personligt, professionelt og socialt gennem at være lyttende, empatisk og anerkendende. Ikke ulig de relationer, undervisere indgår med hinanden i underviser- eller forskningskollektiver.

I undervisningsbaserede kollektiver er det således vigtigt, at de studerende på den ene side oplever, at der er tale om ligeværdige partnerskaber, og på den anden side erfarer, at underviseren tager ansvar for processen og er kollektivets mentor samt ansvarshavende for undervisningsdesignet og dets professionelle, sociale og personlige implikationer. Underviseren er således etisk forpligtet til ikke at lade de studerende i stikken som 'selvstændige forskere'. Selvom underviser og studerende er ligeværdige forskere, betyder det således ikke, at de er ligevidende eller lige- 
$\emptyset$ vede forskere i disse processer.

Omvendt er det vigtigt, at underviseren ligeledes er etisk forpligtet til at sikre, at de studerende ikke blot kommer til at lege forskere i forskningsimiterende processer, at de studerende udover at være studerende nu ydermere skal være forskere i forskningsparallelle processer, eller at de studerende agerer forskningsassistenter $\mathrm{i}$ underviserens egne forskningsprojekter i stedet for at være ejere af egne forskningsprocesser og -produkter i den forskningsproducerende undervisning.

På tværs af grupperne i det undervisningsbaserede forskningskollektiv bliver det således tydeligt, at skiftet fra forskningsbaseret til forskningsproducerende undervisning ligeledes kræver et skifte i roller, fra underviser og studerende til ligeværdige partnere og mennesker i det medborgerhus, der er universitetet, og som selv befinder sig i en ligeværdig dialog med sin omverden: "Academic citizenship occurs when the university becomes a place where the 'they' is being dissolved, when university, society and people are nested within each other" (Nørgård \& Bengtsen, 2016, s. 12). Disse erfaringer kan sammenfattes i en række retningslinjer for akademiske partnerskaber og forskningsproducerende undervisning på modus 3 universitetet:

- Fokus på didaktisk visdom og dømmekraft i designet af undervisning, der sætter universitetets partnere og deres behov, oplevelse og livsverden over systemiske behov.

- Anerkendelse af eksistensen af shadowy siblings i forskningsproducerende undervisning og akademiske partnerskaber, som der arbejdes iterativt og intentionelt med gennem evalueringer og inddragelse af de studerende som partnere $i$ undervisningsdesignets videre udformning.

- Forpligtigelse til ikke at lade de studerende i stikken som selvstændige forskere. Ligeværdige forskere betyder ikke ligevidende eller ligeøvede forskere, og forskningsproducerende undervisning kræver en underviser, der på en gang er partner, mentor og menneske.

- Ansvarlighed for, at de studerende ikke ender med at fungere som ulønnede assistenter/statister eller en gratis uudnyttet ressource. Universitetet og undervisere skal passe på ikke at blive parasitter på de studerendes tid/produktion.

- Tilrettelæggelse af processer, der er egentlig forskningsproducerende, sådan at de studerende ikke kommer til at lege forskere i forskningsimiterende processer eller være forskere sideløbende med, at de er studerede i forskningsparallelle processer.

Disse retningslinjer kan, kombineret med artiklens rammeværk, teoretiske grundlag og empiriske fund sammenfattes i nedenstående 6 principper for undervisningsbaserede forskningskollektiver på modus 3 universitetet:

1. Underviseren som mentor: Studerende fungerer som kollektivets ejere og producenter af studenterinitierede og -drevne forskningsprocesser.

2. Sammenvævet og hybridt samspil: Studerende, undervisere, universitet og samfund er i dialog med hinanden gennem undervisningen og fungerer som partnere i kollektivet.

3. Understøttet og iterativ forskningspraksis: Underviseren fungerer som mentor, der gennem iterationer opøver forskningspraksis i kollektivet med henblik på kollektivets 
transformation af interne studenteropgaver til eksterne forskningsprodukter med samfundsværdi.

4. Kollektiv og deltagende forskningsproducerende undervisning: Underviseren agerer medforsker og medtænker i kollektivet, hvor undervisningen har form som dialogiske samspil frem for monologisk orkestrering. Undervisningen skifter fra at være forskningsinformeret eller forskningsbaseret til at være forskningsproducerende med fokus på de studerendes gennemgående forskningsproces.

5. Den studerende som akademisk medborger $i$ samfundet: Dannelse til akademisk medborgerskab gennem forskningskollektiver som refleksive deltagende akademiske fællesskaber med henblik på medborgerlig samfundsværdi gennem at indgå i dialog og interaktion med omverdenen på akademiske måder.

6. Universitetet som åbent medborgerhus: Undervisning som en integreret del af universitet og omverden, hvor de studerende er ligeværdige partnere på såvel universitet som i omverden. Omverdenen integreres i undervisningen, og undervisningen flyttes ud i omverdenen gennem oprettelsen af forskningskollektiver hvor universitet og omverden mødes.

Sammenlagt peger vores unders $\varnothing$ gelse af undervisningsbaserede forskningskollektiver på, at de kan fungere som katalysator for modus 3 universitetet, hvor studerende, underviser og omverden indgår i ligeværdige dialogiske partnerskaber med hinanden. Undervisningsdesignet er således ét bud på, hvordan man kan operationalisere modus 3 universitetet, der hidtil kun har været omtalt som potentiel 'værensform', til didaktiske formater.

Universitetspædagogisk kunne det således være interessant at unders $\varnothing$ ge, hvordan andre fagtraditioner kan arbejde med at etablere undervisningsbaserede forskningskollektiver fremfor traditionel holdundervisning, og unders $\varnothing$ ge hvorvidt de studerende oplever samme $\varnothing$ gede ejerskab og engagement, som var tilfældet i vores unders øgelse. Ligeledes kunne det være interessant at unders $\varnothing$ ge, hvilke andre didaktiske formater der kunne manifestere sig med udgangspunkt i de her beskrevne rammeværk, retningslinjer og principper.

Endelig kunne det være interessant at undersøge modus 3 universitetet og dets didaktiske formater fra et samfundsperspektiv gennem at unders $\varnothing$ ge, hvordan sådanne partnerskaber og akademisk medborgerskab opleves, og hvorledes en ligeværdig dialogisk forbindelse til universitetet kan opleves som produktiv og værdiskabende.

Rikke Toft Nørgård er associate professor in educational design \& technology på Center for Undervisningsudvikling og Digitale Medier, Aarhus Universitet. Hendes arbejde fokuserer på intentionel innovation i undervisning og læring gennem brugen af designtænkning, uddannelsesfilosofi og signaturpædagogik. Hun har for nylig givet keynotes på CHED'17-konferencen i Shanghai med titlen "Teachers as Learning Designers" og \#dariahTeach-konferencen i Lausanne med "New (infra)structures for the future university". Hendes nyeste publikationer arbejder med at udvikle nye former for undervisningsaktiviteter og universitetskonfigurationer, der relaterer sig til modus 3 universitetet, bl.a. "Academic citizenship: a call for the placeful university" (Nørgård \& Bengtsen, 2016) og "Participatory Academic Communities" (Aaen \& Nørgård, 2015).

Kim Haagen Mathiesen er nyuddannet kandidat i IT-didaktisk design 2017, hvor han afleverede specialet med titlen 'MOOCs: Fanget i en vidensøkonomi, på vej mod et økologisk universitet' 
(2017). Hans interesseområde centrerer sig omkring online-læring, social læring og samskabende undervisning mellem studerende, underviser og omverdenen. Kim har tidligere udgivet artiklen 'Critical reflection and dialogical learning design: moving MOOCs beyond unidirectional transmission of content' (2016) i Læring og Medier, samt paperet 'Med MOOCs som case: Studerendes videnskabelige processer og produkter i undervisningsbaserede forskningskollektiver'(2017) til DUN-konferencen 2017.

\section{Referencer}

Aaen, J.H., \& Nørgård, R.T. (2015). Participatory academic communities: A transdisciplinary perspective on participation in education beyond the institution. In C.M. Reestorff, C. Stage, J.L. Stephensen, L. Fabian, J. Fritsch, K. Samson, et al. (Eds.), Conjunctions. Transdisciplinary journal of cultural participation, Special issue on Participation across, between an beyond disciplines and institutions (pp. 67-98). Aarhus: The State and University Library Aarhus.

Barnett, R. (2011). Being a university. London: Routledge.

Barnett, R. \& Bengtsen, S. (2017). Universities and Epistemology: From a Dissolution of Knowledge to the Emergence of a New Thinking. Education Sciences, 7(1), 38, s. 1-12.

Bengtsen, S. \& Barnett, R. (2017 - in press). Realism and education: A philosophical examination of the 'realness' of the university. I P. Higgs \& Y. Waghid (Red.). A Reader in Philosophy of Education (s.121-137). Capetown: JUTA \& Company.

Brew, A. (2003). Teaching and Research: New relationships and their implications for inquirybased teaching and learning in higher education. Higher Education Research \& Development, 22(1), 2003, s. 3-18.

Collins, A., Joseph, D. \& Bielaczyc, K. (2004). Design Research: Theoretical and Methodological Issues, Journal of the Learning Sciences, 13(1), s. 15-42

Dalsgaard, P (2010). Research in and through design: an interaction design research approach, OZCHI '10 Proceedings of the 22nd Conference of the Computer-Human Interaction Special Interest Group of Australia on Computer-Human Interaction, s. 200-203.

Fairclough, N. (2003). Analysing Discourse: Textual Analysis for social research. London: Routledge.

Flyvbjerg, B (2010) Fem misforståelser om casestudiet. I Brinkmann, S. \& Tanggaard, L. (Ed.), Kvalitative Metoder - En grundbog (pp. 462-487) Danmark: Hans Reitzels Forlag.

Fung, D. (2017). A Connected Curriculum for Higher Education. London: UCL Press.

Healey, M., Flint, A., \& Harrington, K. (2014). Engagement through partnership: students as partners in learning and teaching in higher education. York: Higher Education Academy.

Heidegger, M. (2014 [1926]). Væren og Tid (2. Udgave, 1. Oplag). Århus: Forlaget Klim.

Kozinets, R. (2015). Netnography - Redefined. London: Sage Publications.

Leat, D. \& Reid, A. (2012). Exploring the role of student researchers in the process of curriculum development. The Curriculum Journal, Volume 23(2), s. 189-205. 
Lewis, A., Smith, D. (1993). Defining Higher Order Thinking. Theory into Practice, Vol. 32(3), s. 131-137.

Mathiesen, K.H., Nedergaard, M.H. \& Nørgård, R.T. (2016). Critical reflection and dialogical learning design: moving MOOCs beyond unidirectional transmission of content. Tidsskriftet Læring og Medier (LOM), Vol 9(16), s. 1-33.

Matthews, K.E. (2016). Students as Partners as the Future of Student Engagement, Student Engagement in Higher Education Journal Vol 1(1), s. 1-5.

Mor, Y. (2009). Design Research Cycle. Lokaliseret d. 9 december 2017 på: https://designedforlearning.wordpress.com/2009/07/04/design-research-cycle/

Nixon, J. (2008). Towards the Virtuous University: The Moral Bases of Academic Practice. London: Routledge

Nørgård, R. T. (2014). Open formations: networked thinking and tinkering: Rethinking the People, Processes and Products of Learning Contexts as Open Formations. Working paper from Rethinking Educational Ethnography: the learning context", Copenhagen 3.-4. june 2014.

Nørgård, R.T. \& Bengtsen, S.S.E. (2016). Academic citizenship beyond the campus: a call for the placeful university. Higher Education Research \& Development. Special Issue: New frontiers: exploring the space/s of higher education, Vol 35(1), s. 4-16.

Nørgård, R.T. \& Mathiesen, K.H. (2017). Med MOOCs som case: Studerendes videnskabelige processer og produkter i undervisningsbaserede forskningskollektiver. Paper fra DUN Konference 2017, Vejle, Danmark.

OECD (1996). The Knowledge-based Economy. Lokaliseret d. 9 december 2017 på: https://www.oecd.org/sti/sci-tech/19130 21.pdf

Ossa-Richardson, A. (2014). The Idea of a University and its Concrete Form. I: P. Temple (Red.), The physical university: Contours of space and place in higher education (s. 131-158). London: Routledge.

Polanyi, K. (2001). The Great Transformation: The Political and Economic Origins of Our Time. Boston: Beacon Press.

Regeringen (2006). Progress, innovation and cohesion: Strategy for Denmark in the global economy. Lokaliseret d. 9 december 2017 på: http://www.stm.dk/multimedia/PROGRE SS INNOVATION AND COHESION.pdf

Rygaard, M.F. \& Nørgård, R.T. (2018). En signaturpædagogisk tilgang til implementeringen af unders $\varnothing$ gelsesbaseret fjernundervisning i folkeskolen: designprocesser og pædagogisk rammeværk for fagdidaktisk design af online teknologier og systemer i naturfagsundervisningen. Læring og Medier (LOM), under udgivelse.

Schumar, W. (1997). College for Sale: A Critique of the Commodification of Higher Education. London: Routledge

Selwyn, N. (2014). Distrusting educational technology: Critical questions for changing times. London: Routledge. 
Simpson, P. Mayr, A. (2010). Language and Power: A resource book for students. London: Routledge.

Stakes, R.E.(1995) The Art Of Case Study Research. London: Sage Publications.

Wright, S. (2016). Universities in a knowledge economy or ecology? Policy, contestation and abjection. Critical Policy Studies, Vol. 10(1), s. 59-78. 